\title{
Discussion on Ecological Marxism in Reflection on Technology
}

\author{
Zhongjie Wang \\ School of Marxism \\ Wuhan University of Science and Technology \\ Wuhan, China 430065
}

\author{
Huijie Zhang \\ School of Marxism \\ Wuhan University of Science and Technology \\ Wuhan, China 430065
}

\begin{abstract}
With the appearance of serious ecological crisis, a trend of ecological criticism rises in western countries including Ecological Marxism. The Ecological Marxism combines the green ecological environment with the red socialism and uses ecological activities to provide realistic references for socialism. It uses acute theoretical perspectives and realistic sense of responsibility to have an insight into the correlation of technology and ecology; sharply criticizes the great damage to environment by technology application under capitalist system. The perspective in drawbacks of technology application under contemporary capitalist system provides important enlightenments for technological development in the future, makes us firmly follow the socialist road and promote the benign development of technology and ecology.
\end{abstract}

\section{Keywords—ecological Marxism; ecology; technology}

\section{INTRODUCTION}

With the appearance of global warming, environmental pollution in river, ocean and air, people have ecological crisis. In order to solve serious ecological crisis, science and technology regarded as No.1 productive force by Marx becomes the main object on which scholars and the public reflect. The Ecological Marxism deeply reflects on and criticizes science and technology under capitalist system, providing beneficial enlightenment for our country to reasonably use technology in the ecological development.

\section{ORIGIN OF ECOLOGICAL MARXISM UNDER ENVIRONMENTAL CRISIS}

\section{A. Global Dimension of Ecological Problems}

Ecological problems are the product of social development. As the unbridgeable development stages of human historical development, the industrialization and modernization processes bring negative effects in the rapid economic development. The deterioration of natural and social ecology is prominent. In the industrialization process, human continuously use resources to benefit mankind and obtain from nature; meanwhile, the capitalism wealth ceaselessly accumulates and expands. The extensive application of technology plays a crucial role in it. The profit-seeking nature and the logic of constant expansion in capitalism make bourgeoisie value economic interests most. The application and development of technology also base on profits. Because of the anti-ecological nature of capitalist system, the capitalism will have inevitable and irreconcilable contradictions and conflicts with nature. Besides, because of the propelling of interests of classes and groups and the limitation of subjective and objective conditions in decision making, the technological development of capitalist countries cannot get effective control of the society. Therefore, in the industrialization process of capitalism, people excessively obtain from nature regardless of the bearing capacity of natural environment, let alone its negative effects. Finally, it leads to the serious imbalance of human and natural environment and further intensifies the contradictions between people.

Facing the increasingly deteriorating natural environment, the bourgeoisie fails to restrain their desires in occupying wealth. Instead, they continuously expand, promote the globalization of capital and seek more wealth worldwide.

With the development of economic globalization, in order to relieve environmental deterioration and get sustained profits of the original enterprises, developed capitalist countries transfer enterprises causing heavy pollution to developing countries and continuously expand the global dimension of ecological crisis. Under the tendency of economic globalization, developing countries pay heavier price than developed countries for self-development, including suffering from the bad results caused by destruction of ecological environment. The continuous deterioration of ecological environment makes people understand ecological crisis is an inevitable product of industrial civilization that conquers and dominates nature. It is determined by basic structure and operation mechanism of industrial civilization.

\section{B. Development of Ecology Theory}

With the global ecological crisis, in the 1960s and 1970s, activities about ecological environment fighting for production conditions appeared in western developed countries. The global ecological problems highlight the limit problem of natural crisis and environment for human survival and development. Activities about ecological environment make people reflect on science and technology and its application and have ecological consciousness meanwhile maintain ecological balance through practical action. The green ecological movement is pushed to the most significant end of new social movements in capitalist countries. "In the past twenty to thirty years, the increase of environmental and social 
problems had been beyond the prediction of any theory." [1] At the meantime, works related to system theory, ecology and futurology were published in western society, such as Small Is Beautiful of E. Schumacher, the Limits to Growth of the Club of Rome and the Plundered Planet of H. Gruul. Ecology explains the relationship between human and nature from the perspective of ecological unity instead of the objectivity. It claims to stop the destruction of nature and the pollution of biosphere from industrial development. The development of modern industry should depend on the environment, develop benign reproducible production and ensure human survival. With the occurrence of modern scientific system theory, life sciences got great development in the twentieth century. Researches on life system are ever-deepening. In the 1950s, American scholars raised the concept of "environmental sciences" which comprehensively researches the environmental changes caused by human activities and how to control the changes adverse to human. New theory provides powerful scientific weapon for people to more clearly recognize the internal essence of successive energy and ecological crisis successively in the twentieth century. People gradually realize the importance and urgency of problems about ecological environment and the vindictive act of nature for human and have ecological consciousness. The production and development of ideas and actions also reconstruct philosophy. Ecological philosophy appears with people's awakened awareness of ecological significance. "Land Ethics", "Species Discrimination", "Inherent Value of Nature", "Intergeneration Ethics", "Animal Rights" and "Anthropocentrism" become themes discussed in ecological philosophy. The appearance of ecological philosophy reflects human bid farewell to the era of industrial civilization and enter a new era of civilization namely the era of ecological civilization. It rethinks the position of people in the world from the height of philosophy, relocates the relationship between human and nature and reconsiders the value of nature, and then advocates the sustainable life style and attitude towards life. The development of ecological philosophy is the resurgence of nature and symbolizes people have a more profound understanding about the relationship between human and nature.

Ecological Marxism appears under this background. In order to solve the natural crisis and the crisis of human caused by capitalist mode of production, people integrate the researches on natural philosophy with the criticism on capitalism and reconstruct the relationship between nature and society, natural history and human history. Forster addresses, the worldwide ecological criticism on the capitalist world economy bases on three propositions, "First, a system is unsustainable in the long run if it pursues endless geometric growth and seizes wealth without limitation, no matter how reasonably it uses natural resources; second, a system will be incompatible with ecological stability and "Land Ethic" if it separates people from their sense of belonging and ecological foundation; third, a system is unacceptable if it splits the earth and produces the "poor and rich ecological environment". [2]

\section{CRITICISM OF ECOLOGICAL MARXISM ON TECHNOLOGY}

\section{A. Technological Application of Capitalism Is Purposed to Pursue the Maximum Profit}

Ecological Marxism observes the logic and sole purpose of capitalistic production is to pursue profits as many as possible, so that the labor productivity must be improved to increase the product quantity. Therefore, the energetic development of technology becomes the basic premise for operation and development of capitalistic production. Technology becomes the necessary means and tool for capitalism to develop production. Capitalism is against nature through intermediate links between it and nature, including technology. Capitalists must continuously adopt new technological means to gain maximum profits. However, under capitalist social conditions, the application of new technology conforms to its production logic. It inevitably will damage the ecological environment and lead to ecological crisis and finally become social and political problems. The attitudes of capitalism toward technology base on profits instead of environmental factor.

O'Connor observes the technology of capitalism has three economic functions: first, it makes the unit labor time in workplace get maximum appreciation in production to improve labor productivity and profits; second, it reduces the cost in raw materials and fuel, or improves the service efficiency of raw materials and fuel; third, it expands potential consumer market through developing new consumer goods. The application of technology under capitalism condition closely links to society, politics, ideology and economic connotation. The social formation of capitalism determines the tendency of technological development is that the technology greatly influencing environment will replace the technology having small environmental impact, in order to realize significant growth of profits. Nature is the premise of capital, and the profit taking is the sole purpose of capital. Industrial pollution is destroying biological capital provided by ecological system for production. The overdevelopment of technological system on natural environment causes increasingly severe imbalance between human and nature. It seems the constantly developing technology brings prosperity for economy. In reality, it draws ruin upon itself. Ecological Marxism clearly sees under the capitalist system, technology in favor of capital expansion will develop, while technology adverse to capital expansion will be excluded. Therefore, they emphasize technology shouldn't be blamed. The ecological problems are caused by the application of technology in capitalism instead of technology itself. The technological type and use pattern chosen by capitalist production relations cause ecological problems. If a new productive relation replaces capitalist production relations and correctly uses science and technology conducive to ecological environment, science and technology will benefit mankind.

\section{B. The Technology of Capitalism Can Be Used to Control Ideology}

Most western scholars think science and technology is the result of human wisdom without class and political nature, belonging to the product of non-ideological culture. But 
Ecological Marxism observes in contemporary capitalist society, the "neutrality" of technology has disappeared. It has become the tool of capitalism in political rule to form material and cultural forms required by them, in order to control the whole society. Habermas thinks science and technology is by no means neutral, instead, it has clear political intention and controls ideology of the society. Anyone and any field cannot get rid of its control. As an overall system and cultural form, in defending the rationality of existing society, science and technology replaces the traditional ideology and has fraudulence. It is an indispensable tool to maintain the unreasonable capitalist system. Gorz clearly addresses, "technology-neutral theory" is the myth in construction of privilege and power. It fails to see science and technology is not independent of the dominant ideology. Science and technology serves and integrates in production and takes capitalistic production as the symbol.

\section{Selection and Realization of New Technology}

Marcuse thinks one of the keys to solve ecological crisis is to build the development direction of science and technology conforming to human nature and ecology. Agar advocates a small scale disperse technology between the advanced technology and the traditional technology, using small scale technology to replace highly centralized modern big industrial technology with high energy consumption to furthest keep the integrity of environment. The small scale technology said by him is the "intermediate technology", "democratic technology" and "technology of humanity" proposed by British economist E.F. Schumacher, adapting to ecological law and respecting human nature. [3] Small scale technology does small harm to environment because of the small resource consumption. O'Connor thinks the technology after transformation is "good technology" fundamentally different from "bad technology". "Good technology" refers to the technology with ecological rationality instead of ecological hazard. Pepper thinks "good technology" has two characteristics: first, it adapts to nature and will not damage it; second, it strengthens the ability and control force of producer. Gorz addresses, we should advocate a "soft technology" that is very easy to learn and effective without polluting the environment, such as geotherm and solar energy. It has dispersed investment and small scale and produces safe and clean energy. The adoption of "soft technology" makes people realize high-level independent selfgovernance, self-management and choose new pattern of economic development. All in all, although different scholars of Ecological Marxism have different propositions in selection of new technology, they select ecological standard. Namely, new technology must makes for ecological environment.

On the realization of new technology, O'Connor advocates using environmental struggle and ecology movement to standardize production technology and process and forbidding harmful technology. Besides, combine the struggle in objecting to "bad technology" and pursuing "good technology". Of course, the struggle is extremely difficult and complicated and cannot have effectiveness in the short run.

\section{POSITIVE SignifiCANCE OF ECOLOGICAL MARXISM IN REFLECTING ON TECHNOLOGY}

Ecological Marxism analyzes the phenomenon of "alienation of science and technology", researches the close relationship between science and technology and social and political system and reveals "application of technology in capitalism" and "capitalist nature of industry" in capitalist society. It is incompatible with the anti-technology and counter-production theory of the postmodernism. Strictly speaking, it is antagonistic to opinions in postmodernism. Ecological Marxism opposes to simply attributing the ecological crisis in society to industrialization, science and technology and discussing the damage of science and technology through separating from relation of social production and political system. It advocates finding the causes of ecological crisis in capitalist system and thinks the primary cause of ecological crisis is technological type and use pattern in capitalist production relations. The ecology movement advocated by it is not to stop economic growth and limit consumption but to reasonably choose technology and carry out ecological conversion of technology. Ecological Marxism profoundly reveals the greedy, predatory, savage and unreasonable capitalist system under the perspective of ecological environment instead of simply follows the criticism for capitalism by Marxism. It expands a new field under the historical background of scientific and technological development.

\section{A. Fully Realize the Value of Science and Technology}

Science and technology has instrumental value, humanistic value and ecological value, referring to the aggregation of many values. In the constant expansion of production in capitalism system, people only value its instrumental value. Technology shows strong utilitarianism. Its humanistic value and ecological value are covered by practicality. The one-sided technological rationality will inevitably lead to unreasonable application of science and technology and global issues like energy crisis, resource crisis and environmental pollution. [4]

\section{B. Correctly Treat the Dialectical Relationship between Technological Advancement and Economic Environment}

The development of social economy cannot do without technological application, which is accompanied by environmental pollution and ecological damage. It seems as though technology is opposite to ecological environment. In reality, the contradictory state between them really exists. However, we should see the correlation dependence between technology and ecological environment. With the continuous development of social economy, the limited natural resources are increasingly scarce. Enormous renewable resources exist in nature but it cannot be developed and used through the existing technological level. In order to really make use of renewable resources and solve ecological problems caused by excessive usage of limited natural resources, we must depend on technological advance. Therefore, no inevitable contradictions exist among technological advance, economic development and environmental protection. They will promote mutually through proper disposition. The development of industrial technology form will inevitably reduce material consumption 
and energy consumption of products, improve product quality and prolong the service life of products and then relieve the pressure on ecological system from production activities. Meanwhile, the progress, popularization and application of environmental protection technology are the technological base to realize cleaner production. In the social and economic development, we should give priority to develop technology and transform traditional industries; strengthen the research and development of environmental protection technology, and promote the coordinated development of production and environment. [5]

\section{Strengthen the Research on Social Control of Modern Technological Application}

In the rapid development of capitalist economy, people see technology plays a crucial role in it. Driven by the high profits of capitalism, people continuously develop and extensively apply new technology. Diversified new products emerge in endlessly. All sorts of strange products beyond people's imagination in the past are manufactured. The using range of resources becomes unmeasured vastness with the extensive application of technology. The application extends from land to ocean, underground to outer space. People conquer land and water, sky and underground so that they become more and more conceit, declaring they can conquer nature. When the conquerors get dizzy with success, nature begins to counterattack and revenge.

Unrestrained application of technology causes severe damage to ecological environment, dealing a direct blow at conquerors. People reflect on whether their behaviors are appropriate and whether the idea of controlling nature is legal. Facing the serious ecological crisis, people finally realize we should control behaviors of ourselves instead of nature; use technology responsibly and restrainedly, especially control technological application from system level. As the largest developing country, our country has made great achievements in economy. At the meantime, we bring problems for ecological environment. In order to solve it, corresponding legal system should be formulated to effectively control technological application. First, in technological innovation, we should think whether the application of technology can achieve comprehensive and organic unification of ecological benefit, economic benefit and social benefit instead of only considering the economic benefit; second, establish scientific standard to evaluate new technology. A new technology must be evaluated comprehensively and objectively prior to application, in order to know the negative effects after application, whether corresponding countermeasures exist. The technology cannot be applied if the countermeasures are not prepared; third, a system of public opinion about ecological education exists to guide people consciously use technology with goodwill. Once people use technology maliciously and damage ecological environment, they will suffer from powerful pressure from public opinion even deserve severe punishment.

\section{Develop Ecological Functions of Advanced Technology to Realize Sustainable Development of Society}

In the 21 st century, our country inevitably encounter three population peaks and the excessive use of energy and natural resources, accelerate the reversion of right side on the "inverted U-shaped curve" of ecological environment, narrow the development gap between regions and solve issues of agriculture, build the ability of sustainable development and cultivate international competitiveness. Development is the absolute principle. Technology is an important support. We must establish correct outlook on technological development, effectively resist ecological colonialism and develop the ecological functions of advanced technology.

Nowadays, the technological development shows obvious duality: first, the scale and influence of technology enlarge infinitely; second, the diversified development of technology makes technology dispersed. In the future society, the technological development is the unification of the two tendencies. If we fail to abide by the objective law of technological development but one-sidedly advocate small scale technology, we will be caught in subjectivism. [6] In fact, in order to solve ecological crisis, the scale of technology is not the priority. We should advocate green civilization and sustainable development and develop ecological technology with profound cultural deposits. Meanwhile, transfer the core of technology system from the perspective of ecological functions and reasonably recombine technological structure, in order to transfer from hard technology system to soft technology system and truly achieve the "greening" of advanced technology.

\section{CONCLUSION}

Ecological Marxism takes ecological problems as a logical starting point. The evaluation standard of social development no longer depends on the economic index of the society but includes ecological cost. Nowadays, under the background of globalization, our country is the largest developing and socialist country. Facing international competitive pressure and domestic pressures, we must follow the road of sustainable development and choose sustainable development mode with economic, social and ecological integration. Therefore, in the future technological development, our country must strictly follow the sustainable development mode and bring the consumption of natural resources and the impact on environment from activities of material production in human ecological system, in order to realize virtuous cycle and sustainable development of interchange of materials and energies inside the ecological system, meanwhile, realize the economic and social sustainable development on the basis of respecting nature.

\section{REFERENCES}

[1] James O'Connor: Reasons of Nature, Ecological Marxism Research, translated by Tang Zhengdong, Nanjing University Press 2003 Edition, p2

[2] John Bellamy Foster: Ecological Crisis and the Capitalism, translated by Geng Jianxin, Shanghai Translation Publishing House 2006 Edition, p83 
[3] E.F. Schumacher, Small Is Beautiful, translated by Yu Hongjun, the Commercial Press 1984 Edition, P2

[4] Ren Kai: The Green Dimension under the Perspective of Science and Technology, Technology View of Western Ecological Marxism, Jianghan Tribune, the 7th issue of 2007, p46

[5] Wang Ansheng: Review on Ecological Marxism, Social Sciences Review, the 2nd issue of 1997, p28

[6] Wang Shitao, Yan Hongyuan: Analysis on "Ecological Marxism", Philosophical Trends, the 2nd issue of 2000, p44 